\title{
THE CONSEQUENCES OF SUPERVISORY LAW ON THE REGIONAL REGULATIONS WITH LOCAL CHARACTERISTICS
}

\author{
Victor Juzuf Sedubun \\ Faculty of Law, Pattimura University \\ Email:v.j.sedubun@gmail.com
}

\begin{abstract}
The present study investigates the consequences of supervisory law on the regional regulations with local characteristics. The study is normative with regards to the commandment and conceptual approaches. The consequences of supervisory law on the regional regulations with local characteristics, according to Article Number 251 verse 1 and 2, are dismissed ('vernietigbaar'). 'Vernietigbaar' is 'ex nunc' that means 'since the moment'. As a consequence of the law, the dismissal of regional regulations is valid until it is issued by the regional government. Due to the existing supervisory law performed by the Supreme Court, the judge declares the regional regulations 'invalid' since they are lack of powerful relevant laws. The Regional Government took a legal action on the issue of dismissed regional regulations by submitting an objection to the Supreme Court.
\end{abstract}

Keywords: the consequences of the supervisory law, regional regulations with local characteristics

\section{A. INTRODUCTION}

The termination of regional regulations performed by the Ministry of Domestic Affairs has caused a legal issue on the authority of terminating the regulations. The Law Number 32 of 2004 and the Government Regulations Number 79 of 2005 stated that the termination of regional regulations is under the authority of the Government by the Presidential Decree. Meanwhile, the termination of regional regulations was conducted by the Ministry of Domestic Affairs by issuing the decree of the Minister of Domestic Affairs.

Central government as the authority holder is obliged to perform supervisory towards all the privileges the regional government has in order to 
avoid the contradiction of using the privileges carelessly. On the other hand, the regional government is responsible to carry out the authorities in accordance with the agreed regulations to meet the expected aims.

The using of authority by the administration officers is a part of administrative law. So, in dealing with the authority, the administrative officers have to refer to basic components of the administrative law. According to Hadjon (Hadjon, et.al., 2010:19), the three basic components of administrative law encompass the law of holding the governance, the law by the government, the law for the government that is the law involving legal protection for all citizens towards the government's actions. In line with Hadjon's statement, the termination of regional government is an activity that includes the three basic components of administrative law aforementioned, more specifically of the law of holding the governance, because the termination of regional regulations is a share of the control towards holding the governance in the region. Based on administrative law, there are three types of termination, that are vernietigbaar (can be terminated), nietig (terminated), and nietigheid van rechtswege (terminated by law), meaning that the invalid verdict of administrative boards/officers can result to the state of can be terminated, terminated, or terminated by law.

The control of the issue on regional regulations performed by the Government and the Supreme Court is based on the authority owned by each of the supervising institutions. The control by those two institutions is implemented through the mechanism of executive preview and executive review by the Government and judicial review by the Supreme Court. The control by either the 
Government or the Supreme Court will impact on the legal consequence that can be viewed from two aspects, namely the valid time and the occurred consequences for the regional government and society.

\section{B. RESEARCH PROBLEM}

Based on the background of the study aforementioned, the research problem is: What are the consequences of supervisory law on regional regulations with local characteristics?

\section{RESEARCH METHODS}

The research uses a normative study that aims at investigating the positive legal regulations and legal principles and explaining and projecting the direction of law development in the future. The study uses a statute and conceptual approaches. The inventory was conducted towards primary and secondary legal materials and they were then classified. The next stage was to analyze the legal approaches to acquire a synchronized level of all legal materials that had been tested and compared to legal theories and principles to be finally analyzed normatively. The result of the analysis indicates the arguments to suggest some prescriptions to solve the analyzed problem.

\section{DISCUSSION AND RESEARCH RESEARCH}

1. The Consequences of Supervisory Law on Regional Regulations with Local Characteristics

a. The Time Applies on the Decree of Terminated Regional Regulations by the Government 
The supervisory of regional regulations based on the Law Number 23 of 2014 is classified into two types, namely preventive and repressive supervisory. The preventive supervisory is performed by making clarification along with its assessment, while repressive supervisory is done through evaluation.

The termination of regional regulations may lead to legal consequences because it was done after the regulations were stipulated, legitimate, and having binding legal force. According to E.Utrecht (Utrecht, 1983: 12), the meaning of legitimate in the regulations is accepted as something definite, while having legal force (rechtskracht) means that the regulations may interrupt legal association.

In accordance with the time applies on the termination of regional regulations, Philipus M. Hadjon (Hadjon, 1985: 25) mentioned as follows:

"The illegitimate verdict may lead to 'nietigheid van rechtswege' (void by law), 'nietig' (null and void), or 'vernietigbaar' (voidable).

'Nietig' for law means that the action taken is considered nothing. As a consequence, there will not be any valid legal consequences. 'Vernietigbaar' based on the law means that the action and the legal consequences are present until there is the termination performed by the judge or other competent government institutions. "van rechtswege nietig" means the consequences of an action for the law is considered nothing, so there is not any necessary judgment to dismiss the performed action.

There is a different regulation mentioned in Article Number 251, paragraph (1) and paragraph (2) of Law Number 23, 2014 as follow: 
(1) Provincial regulations and governor's regulations that are against the higher legal decree, public interest, and/or morality are dismissed by the Minister. (italics by the researcher)

(2) District/city regulations and regent/mayor's regulations that are against the higher legal decree, public interest, and/or morality are dismissed by the governor as the representative of the central government. (italics by the researcher)

Nomenclature of dismissal used in the aforementioned decision is dismissed. Referring back to Philipus M. Hadjon's opinion, the word dismissed can be categorized into 'vernietigbaar' (voidable) that is valid since the moment.

In accordance with the stipulation of dismissing the Provincial and Governor's Regulations and District/City Regulations by the Minister of Home Affairs, Hart and Stelinga, quoted by E. Utrecht (Utrecht, Ibid: 83), stated that:

"een beschikking mag nimmer als van rechtwege nietig worden opgevat, noch in de gevallen, waarin een zodanig beschikking bij de administratieve rechter of administratief beroep kan worden aangetast, noch in de gevaleen, waarin deze mogelijkheden ontbreken."

The stipulation released by the government is not supposed to be void by law, either can be claimed at administrative court and appeals or the claim and appeals can be possibly ignored. This statement is true since if there is government's stipulation that is considered as void by law, it means that the government's action is not based on the legitimate authority, because there is a flaw. Regional regulations as a product of local law is established on the basis of attribution authority arranged in 
the Article Number 18, verse 6 in the 1945 Constitution as a constitutional foundation.

The establishment of regional regulations should also be based on the stages of Law Number 12, 2011, Law Number 23, 2014, and Rules of the Minister of Home Affairs Number 1 of 2014.

The establishment procedure as mentioned above, according to Sukardi (Sukardi, 2009: 188), is potentially away from defective authority but is still pretty close to be affected by the material defects. This is related to the inadequate capacity of Regional Government in understanding its authority because the norms in the constitutions are ambiguous or multi-interpretation.

Philipus M. Hadjon (Sukardi, Ibid: 185) argues that: "governmental action can be void by law, null and void, or voidable depending on whether the inadequacy of the decision is essential". This opinion is along with the conclusion by Van der Wel (Utrecht, Loc.cit.) who states:

"A decision on something totally impossible to implement can be voided at all. Regarding other provisions, we must see whether they are the 'essentieel' defects or not. The weakness of the not 'essentieel' cannot affect the validity of the decisions. Also, the weakness of 'essentieel' can be seen by the level of deficiency. "

Referring to that opinions mentioned above, the dismissal of regional regulations according to Law No. 23 of 2014 using the nomenclature of voided contains the legal consequences that the cancellation of the quo regional regulations starts since now, but its legal 
power is still deemed exist until the dismissal time of the quo regional regulation by the Regional Government.

b. Consequences (Implementation) of Judgment on the Dismissal of Regional Regulations with Local Characteristics for the Provincial

\section{Government and Community}

The arrangement of paragraph (1) and paragraph (2) of Article Number 251 of Law Number 23 of 2014 has the potential to bring impacts on the provincial government and the regional community. The impact is the legal consequences of the dismissal. Referring to the above explanation that the voided nomenclature is categorized as 'vernietigbaar' (voidable) with 'ex nunc' characteristic, then the voided Regional Regulation is considered to exist until its dismissal by the Regional Government. Law consequences of the voided Regional Regulation are all the legal consequences that must be considered to exist until the dismissal and are considered no longer valid since the revocation by the Regional Government.

Referring to the opinion of Hart and Stelinga, quoted by E. Utrecht and cited by Philipus M. Hadjon above, if the provision deficiency is too big to be called as a provision, then the provision can be considered void at all. If the deficiency is not so serious, the relevant provision may be null and void of a law subject that has no authority to claim the provision.

Law Number 23 of 2014 does not give any time restriction for the dismissal of Regional Regulations as stipulated in Law Number 32 of 
2004. Article Number 251 paragraph (4), paragraph (5) and paragraph (6)

of Law Number 23 of 2014 states:

(4) The dismissal of regional regulations and governor's regulations as referred to in verse (1) is established by a decree of the Minister, and the dismissal of the Regency/ City and the regent's/mayor's regulations as referred to in verse (2) shall be established as a Decree of Governor as the representative of the Central Government.

(5) At the latest 7 (seven) days after the dismissal of a provision as referred to in verse (4), the head of the region has to dismiss the implementation of the regional regulations and then the Regional Legislative Assembly along with the head of a region shall revoke the regional regulation.

(6) At the latest 7 (seven) days after the dismissal decision as referred to in verse (4), the head of the region shall dismiss the implementation of the regulations of a head of the region, and subsequently, the head of the region will revoke it.

The provision of Article Number 251 paragraph (4) of Law Number 23 of 2014 does not stipulate the time restriction for evaluating the regional regulation, and the regulated provisions only stipulate the timing of the decision on the regulation dismissal to the head of the region, and subsequently the head of the region along with the Regional Legislative Assembly revoke the regional regulations. This arrangement is agreeable to the provisions of Article Number 251 paragraph (5) and paragraph (6) of Law Number 23 of 2014.

The failure to regulate the time limitation for evaluating the regional regulations could potentially impact regional governments in implementing the regional regulation and for the benefit of local communities. Regional regulation that has been applied for a long time in society and has changed the life of the community that then its 
enforcement is voided by the Government will bring the consequences; that the dismissed regional regulation is considered to never exist, so it must be returned to its original condition.

The dismissal of the regional regulation according to Law Number 23 of 2014 by using the voided nomenclature, contains the legal consequences that the a quo Provincial Regulation is considered to exist until the time of dismissal. Therefore, the use of the voided nomenclature in the annulment of regional regulation, as stipulated in the provisions of Article Number 251 paragraph (1) and paragraph (2) of Law Number 23 of 2014 contains the same meaning with the voidable nomenclature, as regulated in Article 145 paragraph (2) of Law Number 32 of 2004.

The legal step that can be taken by the Regional Government related to the Decree of Government to declare the provincial regulation as regulated in Article Number 145 of Law Number 32 of 2004 is by submitting an objection to the Supreme Court. Article Number 145 paragraph (5), paragraph (6) and paragraph (7) of Law Number 32 of 2004 states that:

(5) If the province/regency/city cannot accept the decree on the dismissal of the regional regulations as referred to in verse (3) by the reasons legalized by the legislation, the head of the region may submit the objection to the Supreme Court.

(6) If the objection as referred to in verse (5) is legalized partly or wholly, the decree of Supreme Court states that the Presidential Regulation is void and has no law force.

(7) If the Government does not issue a Presidential Regulation to cancel the Regional Regulation as referred to in verse (3), the regional regulation is stated valid. 
The provisions of Article Number 145 paragraph (5), paragraph (6) and paragraph (7) of Law Number 32 of 2004 clearly stipulate that the authority to adjudicate objections of the provincial government to the annulment of provincial regulations is in the Supreme Court. The submission of this objection is as a consequence of the voided nomenclature on the decision of the decree of dismissal on the regional regulations.

Voided means that the formatting of regional regulations by the Regional/ Provincial Government is a defect of authority, or it can be said that the Regional Government has exceeded the authority (ultra vires) which is the opposite of intra vires. The definition of intra vires according to S.A de Smith as quoted by Sukardi is within their power, means that they can only do what the law permits them to do. According to Sukardi (Sukardi, Op.cit: 173), the meaning of ultra vires is exceeded its authority. A provincial regulation, for example, can be said as an ultra vires if the law is established but it is the opposite of legislation that delegates its formation of authority.

2. Consequences of Supervisory Laws of Supreme Court on the Regional Regulations with Local Characteristics

a. Time of Decree of the Dismissal of Regional Regulation with Local Characteristics by Supreme Court. 
Based on the theoretical supervision of government law actions, the judicative institution conducts a supervisory function which has exceptional characteristics which are:

1) External control;

2) Controle a-posteriori (supervision after the action has done);

3) Supervision of legality (law), not in terms of benefit (opportunity).

These three characteristics are the truth of a judicial control. According to the valid positive law in Indonesia, this judicial control is in the hands of state administrative courts, based on the authority allowed by the law (Sukardi: 75).

The authority of supervisory of the Supreme Court is based on the legislation regulation, consists of Article 24A Paragraph (1) of the 1945 Constitution, Article 20 paragraph (2) letter b and paragraph (3) of Law Number 4 of 2009 and Article 31 of Law Number 5 2004. Related to the authority of the Supreme Court as stated in Article 24A Paragraph (1) of the 1945 Constitution in connection with Article 20 paragraph (2) letter b of Law Number 48 of 2009 in connection with Article 31 of Law Number 5 of 2004, so the supervisory of Regional Regulation become the Supreme Court's authority. The decision of test of Regional regulation by the Supreme Court is not voided, as long as the decision of test is not contrary with the higher legislation regulation, and its process is appropriate with the valid legislation regulation. 
Bagir Manan (Manan, 2007: 128-129) states the opinions regarding

the above as follows:

"The formulation of Article 11 paragraph (2) letter $\mathrm{b}$ (then changed to be Article 20 paragraph (2) of Law No. 48 of 2009, but with the same formulation-italics by the author), is different with the formulation of Article 26 of Law number 14 of 1970 that states:

(1) The Supreme Court has the authority to declare the lower illegal legislation and regulation that opposite with the higher illegal legislation and regulation.

(2) The decision of the illegality of legislation and regulation is decided based on the supervisory of the highest court level.

(3) The abolishment of the illegality of legislation regulation did by the relevant authority.

The authority of the Supreme Court according to Article 26 of Law number 14 of 1970 is about the invalidity of authority, whereas in Article 11 paragraph (2) letter b Law number 4 of 2004, the authority is about the testing process as mentioned in the Constitution (Republic of Indonesia) of Article 24A. Substantially or understanding (begrip), there is no difference of meaning between the two formulas of authorities. The authority decides about the invalidity only if the Supreme Court has the right to test the legislation (lower than the law). On the other hand, the authority means that the Supreme Court may declare illegality of the legislation regulation (lower than the law) that contrary with the higher level of legislation regulation. This is supported by the Law number 5 the Year 2004, Article 31 Paragraph (4) which states: "the legislation regulation that is declared as the invalid legislation... do not have the force of law."

The gratified description to explain the procedures for the implementation of the right to judicial review by the Supreme Court needs to be interpreted to the appointments of Article 31 of Law number 5 of 2004. According to Philipus M. Hadjon (in Bagiyo, 1994: 51-52), the appropriate interpretation used in understanding the appointments about the procedures of the Material Test Rights material is a systematic interpretation and grammatical interpretation. A systematic interpretation is used to explain the relationship between the appointments of Article 31 
of Law number 5 the Year 2004 and other articles to obtain a deeper into the using of the Material Test Rights.

The systematic interpretation is based on the provisions of the Article 31 paragraph (3) Law number 5 of 2004 states:

1) The words of the legislation regulations shows the relations between Article 31 paragraph (1) states: "The Supreme Court has the authority for supervisory on the legislation regulation under the law and to the law", and paragraph (2) states: "the Supreme Court decides the invalidity of the lower legislation regulation that contrary with the higher legislation regulation".

2) The words of the highest court level mean the supervisory level. So it must be related to the provisions of Article 29 of Law number 14 of 1985 and Article 30 of Law number 5 the year 2004. Article 29 of Law number 14 the year 1985 states "the Supreme Court decides the petition of the highest court to the verdict of a court in appeal or final level". Whereas article 30 paragraph (1) of Law number 5 of 2004 states:

"The Supreme Court in the highest court level revokes the verdict or decision of courts from all of the judicial environments, because:

a) The Supreme Court does not have the authority or exceed the authority

b) The acts are breaking the law

c) It does not fulfill the term of legislation regulation and causes the cancellation of the verdict.

The next step is interpreting grammatically to the provision of Article 31 paragraph (3) of Law number 5 of 2004. It will states more 
clear about the meaning of the conducted interpretation. Article 31 paragraph (3) states" The decision about the invalidity of legislation regulation as stated on paragraph (2) can be accepted about its investigation in the highest court level or based on the direct petition to the Supreme Court.

In doing their duties, judges interpret and also overlooks the law because of the doelmatig, for the justice, contrary with public disciplines, or obviously contrary to law perceptions in the society. Yet, the judge does not have the authority to decide about its invalidity but may to overlook it only. Because to overlook has the individual meaning whereas to declare the invalidity has the general meaning.

The test rights have non retroactive characteristic, so the decision about "the invalidity" means that the voided provisions do not have the force of law since it declared invalid. The consequences, rights, and duties of law that happened before it declared invalid is still considered as valid and must be held.

The declaration about "the invalidity" technically has different meaning with "void". Declaration of the "cancellation/ invalid" (nietig) means that the provision is considered not exist. It based on the statement of Philipus M Hadjon who states: "there are two testing namely ex tunc and ex nunc" (Hadjon, 2007: 193). The ex tunc examination is in evaluating the government's acts, the court will consider the facts and conditions of the occurrence. So, a Regional Regulation is conducted 
based on the fact and condition. Literally, ex tunc means since a long time ago. In the decision of the testing of Regional Regulation, ex tunc means that the act and the consequences are considered never exist. All of the law consequences must be considered never exist and must be restored.

Based on the description above, the appointment of Article 20 paragraph (2) letter b of Law Number 48 of 2009 states that: "testing the legislation regulation under the law and to the law", carefully. This prudence is very important, because "the cancellation" decision of the judge will cause the retroactive characteristic. The judge decides that the tested Regional Regulation is unlawful if does not have the force of law, as regulated in the appointments of Article 31 paragraph (3) and paragraph (5) of Law Number 5 of 2004.

The appointments of Article 26 of Law Number 14 of 1985 about the Supreme Court's decision related to the testing of the Regional Regulation including the appointment that is not amended by Law Number 5 of 2005, so the provisions is still valid. Thus the Supreme Court states that the Regional Regulation has been tested is unlawful. As stated in the appointments of Article 31 paragraph (3) and paragraph (5) that the invalid/ unlawful Regional Regulation does not have the force of law. So, in considering the decision, the judge also need to affirm that "the decision is invalid because it doesn't have the force of the law" 
b. Consequences (Implementation) Decisions of the Cancellation of Regional Regulation with Regional Characteristic by the Supreme Court for the Regional Government and for the Community.

The authority of the Supreme Court to do a judicial review/ material test of the Regional Regulation should be prioritized. It is based on the idea that:

1) Institutionally, the Supreme Court as a higher level than the Minister of Internal Affairs;

2) Based on the appointments of Article 24 of 1945 Constitution of the State of the Republic of Indonesia of 1945, The Supreme Court is the highest judicial authority institution, and based on the Article 24A Paragraph (1) of 1945 Constitution of the State of the Republic of Indonesia has authority to test the legislation regulation under the Law (including Regional Regulation) regarding the Law;

3) In fact, the testing conducted by the institution outside of establishment or supervisory institutions result in the more objective decisions than the testing carried out by the other institution in the same institution.

Based on the appointments of Article 31 and 31A of Law Number 5 of 2004 and the Supreme Court Regulation Number 1 of 2011 on the Material Test Rights, so the people which active in doing supervision to the legislation regulation or the Regional Regulation with Local Characteristics are the interests and rights of community have been 
harmed by the Regional Regulation with Local Characteristics. This supervision is done by submitting the petition of testing of the Regional Regulation to the Supreme Court, either directly submitted to the Supreme Court or through the general judicature court under the Supreme Court.

The Supreme Court Regulation Number 1 of 2011 does not regulate the opportunity for the community to do the supervisory on implementation of testing process by the Supreme Court, it means that the Supreme Court is still covered, whereas the disputed object is the object related to the public interest or a regulation (regeling) in the community.

Based on the supervisory of the Regional Regulation with the local characteristics, so the Supreme Court decides that the Regional Regulation with the local characteristics is illegal/ unlawful. It is stated in Article 6 Supreme Court Regulation number 1 of 2018 states:

(1) The Supreme Court states that the petition of the objection has reasons since the legislation regulation is contrary to higher law or legislation, so the Supreme Court grants the petition of the objection;

(2) The Supreme Court of Justice states that the petition of an objection of legislation regulations is illegal and invalid, and orders the authorities for the revoking;

(3) According to the Supreme Court's opinion about the unreasonable objections, so the Supreme Court rejects the petitions of objections.

Based on the decisions of the Supreme Court about the illegality of the Regional Regulation and has no force of legal, so, according to the 
appointments of Article 28 paragraph (2) of Regulation of Supreme Court Number 1 of 2011:

"In the case of 90 (ninety) days after the decision of the Supreme Court is sent to the Board or the State Administration Officer that issues the legislation regulation, but the Dignitaries concerned does not do its duty, so for the law, the legislation regulation does not have the permanent of the force of law"

The consequence of the unlawful decisions by the Supreme Court is the Regional regulation with local characteristic has no the force of law since the Supreme Court gives the decisions. This consequence is founded since the regional government stopped the implementation or revoked the Regional regulation with the local characteristic. Then the Regional Government and the Regional People's Legislative Assembly makes a new Regional Regulation to change the illegal Regional Regulation and has no the force of law. If after 90 (ninety) days after the decision has been sent to the regional government, but the Regional Government does not revoke the Regional Regulation with regional characteristics which have been declared as the illegal regulation by the Supreme Court, so for the law, the regional regulation has no the force of law.

\section{E. CLOSING}

\section{Conclusion}

The nomenclature of the cancellation of regional regulations in Article 251 paragraph (1) and paragraph (2) of Law number 23 of 2014 is dismissed. Voided/dismissed belongs to the vernietigbaar category (ex 
nunc) which means since now. The law consequences of the voided Regional Regulation should be considered to exist until the time of dismissal by the Regional Government. This is in accordance with the principle of contrarian actus and the principle of presumptio iustae causa. The judge's decision of the test of Regional regulation is "declare the invalidity", means that the tested Regional regulation has no the force of law. The consequence is that the regional regulation has no the force of law since the verdict was declared.

\section{Suggestions}

Suggestions that can be stated are: that the legal steps can be taken by the Regional Government regarding the Decision of Cancellation of Regional Regulation by the Minister of Internal Affairs and the Governor as the representative of the Government in the region as regulated in Article 251 paragraph (7) and paragraph (8) of Law number 23 of 2014, is by submitting an objection to The President (for the Provincial Government) and to the Minister of Internal Affairs (for the Regency / City Government) should be returned to the Supreme Court as stipulated in Article 145 paragraph (5), paragraph (6) and paragraph (7) of Law number 32 of 2004.

\section{BIBLIOGRAPHY}

Books:

Hadjon, Philipus M., 2007, "Law Protections for the People in Indonesia, A Study of Principles, Handling by Court in the General Courts and Establishment of Administrative Court", Peradaban: Surabaya,.

Hadjon, Philipus M., et.al. 2010, "Administrative Law and Good Governance”. Trisakti University: Jakarta 
Manan, Bagir, 2007, “Judicial Power of Indonesia in Law no. 4 the Year 2004, FH UII Press: Yogyakarta

Sukardi, 2009, "Cancellation of Regional Regulations and the Law Consequences", Dissertation, Postgraduate Program of Airlangga University: Surabaya.

Utrecht, Ernst, 1983, “Introduction In Indonesian Law”, Ichtiar Baru join with Sinar Harapan: Jakarta.

\section{Journal:}

Bagiyo, Himawan Estu, "Some Notes about the Material Test Rights of the Supreme Court regard to the Regional Regulations", Juridika, No. 3 Years IX, May-June 1994, Airlangga University, Surabaya, 1994.

\section{Laws and Regulations:}

Constitution of the State of Republic of Indonesia of 1945

Law number 3 of 2009 (Page of the Republic of Indonesia of 2009 Number 3, Appendix Page of the Republic of Indonesia Number 4958) about the Second Amendment to the Law number 14 the Year 1986 regarding the Supreme Court.

Law number 48 of 2009 (Page of the Republic of Indonesia of 2009 Number 157, Appendix Page of the Republic of Indonesia Number 5076) regarding Judicial Power.

Law Number 23 of 2014 (Page of the Republic of Indonesia of 2014 Number 244, Appendix Page of the Republic of Indonesia Number 5587) on Regional/ Provincial Government. 